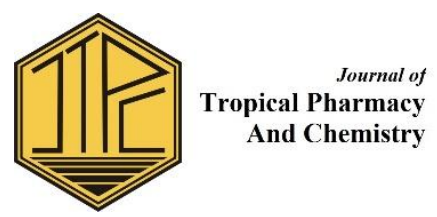

\title{
STUDI PENDAHULUAN FITOKIMIA TANAMAN KOLEKSI ARBORETUM LEGOK PULUS GARUT
}

\author{
Retty Handayani*, Ardi Rustamsyah, Farid Perdana, Setiady Ihsan, Deden Winda Suwandi \\ Jurusan Farmasi, FMIPA, Universitas Garut, Jalan Jati No. 42 Tarogong Garut 44151 \\ *Corresponding Author email: rettyhandayani@gmail.com
}

\begin{abstract}
ABSTRACK
Arboretrum is a botanical garden which is an open place where there are plants that have been labeled. The purpose of this research is the preliminary study on phytochemical content of secondary metabolite compounds on the leaves of the Legok Pulus Garut arboretum collection plant. the results of the study known twenty-two types of plants contained in Arboretum Garut contain various phytochemical compounds and can be used as collection and research base of medicinal plants.
\end{abstract}

Keywords: arboretum, phytochemicals, secondary metabolites

\begin{abstract}
ABSTRAK
Arboretrum merupakan kebun botani yang merupakan tempat terbuka dimana terdapat tanaman yang sudah diberi label. Tujuan penelitian ini adalah studi awal mengenai kandungan / penapisan fitokimia senyawa metabolit sekunder pada daun tanaman koleksi arboretum Legok Pulus Garut. hasil penelitian diketahui dua puluh dua jenis tanaman yang terdapat di Arboretum Garut memiliki kandungan senyawa fitokimia beragam dan dapat dijadikan koleksi serta basis riset tanaman obat.
\end{abstract}

Kata kunci : arboretum, fitokimia, metabolit sekunder.

Submitted on: 8 November 2017 Accepted on: 21 December 2017

DOI: https://doi.org/10.25026/jtpc.v4i2.136

\section{PENDAHULUAN}

Penelitian tanaman dalam pengobatan sangat intensif sejak abad ke20 dengan tujuan mencari obat baru untuk berbagai kondisi penyakit serta menolong dalam penelitian yang berhubungan dengan fitoterapi atau pengobatan herbal dengan fokus dalam pencarian obat baru. Kekayaan dan diversitas flora menjadi sumber obat yang potensi, sebagaian kecil tanaman tercatat memiliki aktivitas biologi dan dari sejumlah tanaman yang ada dibumi (250.000-500.000) spesies baru sebagaian kecil diketahui senyawa fitokimia dan aktivitas farmakologinya. Dipercaya hanya sekitar 50.000 tanaman tingkat tinggi yang bisa digunakan untuk pengobatan dan hanya 5000 tanaman yang sudah dipelajari untuk pengobatan [1]. Indonesia sebagai negara tropis memiliki biodiversitas tanaman dengan potensi keunikan aktivitas biologi, nilai biodiversitas sebagai solusi alternatif untuk kebutuhan dasar manusia (pangan, obat dan energi) yang belum dimanfaatkan [2]. 
Kabupaten Garut dengan luas area $3.065,19 \mathrm{~km}^{2}$ memiliki banyak sekali pegunungan diantaranya 2 gunung aktif (Gunung Guntur dan Papandayan) memiliki nilai kesuburan dan berpotensi dalam memakmurkan rakyat [3]. Garut memiliki Arboretum yang terletak di kawasan Taman Wisata Kamojang di Kampung Legok Pulus Desa Sukakarya Kecamatan Samarang Kabupaten Garut merupakan salah satu Arboretum yang jumlahnya masih terbatas di Indonesia. Sejumlah tumbuhan dibudidayakan di Arboretum tersebut, akan tetapi masyarakat banyak yang belum banyak memanfaatkan arboretum baik sebagai ekowisata, pusat ekologi dan sistematika tanaman maupun tanaman yang digunakan untuk pengobatan dan lainlain.

Penelitian mengenai tanaman khususnya inventarisasi tanaman telah dilakukan sebelumnya oleh Yulianti dari hasil penelitian determinasi diketahui terdapat 27 suku dan 56 spesies tanaman yang terdapat di Arboretum Garut. Suku tanaman yang paling banyak ditemukan adalah Myrtaceae dengan persentase 14,28 \%; selanjutnya berturut-turut yaitu Lauraceae dengan persentase $10,72 \%$; Moraceae dengan persentase 8,93\%; (Euphorbiaceae, Meliaceae, Mimosaceae dengan persentase 5,35 \%); (Anacardiaceae, Elaocarpaceae, Oxalidaceae, Rubiaceae, Sapindaceae, Sapotace, Verbenaceae dengan persentase 3,57 \%); (Annonaceae, Asterales, Araucariaceae,Bignoniaceae,

Casuarinaceae,

Ebenaceae, Hamamelidaceae, Magnoliaceae, Malvaceae, Pinaceae, Podocarpaceae, Punicaceae, Rutaceae, Theaceae dengan persentase 1,78 \%) [4]. Tujuan penelitian ini adalah identifikasi pendahuluan senyawa fitokimia tanaman hasil inventarisasi sebagai dasar penelitian selanjutnya.

\section{METODE PENELITIAN}

\section{Pengambilan Bahan}

Bahan uji diambil dari lokasi Arboretum Garut. Ada sekitar 22 tanaman daun tanaman yang diambil sebagai bahan uji.

\section{Penyiapan Bahan Uji}

Bahan yang dikumpulkan kemudian di cuci, disortasi basah, dirajang, dikeringkan disortasi kering kemudian dibuat serbuk [5].

\section{Pemeriksaan Alkaloid}

Sebanyak 2 g serbuk simplisia dilembabkan dengan $5 \mathrm{ml}$ ammonia $25 \%$ dan digerus dalam mortir, kemudian ditambahkan $20 \mathrm{ml}$ kloroform dan digerus kuat-kuat. Campuran disaring, filtratnya digunakan untuk percobaan (larutan A). Larutan A diekstraksi 2 kali dengan larutan asam klorida $10 \%$ (larutan B). Larutan A diteteskan pada kertas saring, ditetesi pereaksi dragendorf. Pengamatan positif bila timbul warna merah jingga. Larutan B sebanyak $5 \mathrm{ml}$ dalam tabung reaksi diuji dengan penambahan pereaksi Mayer dan Dragendorf. Pengamatan positif bila timbul endapan merah bata pada penambahan peraksi Dragendorf dan endapan putih pada penambahan pereaksi Mayer.

\section{Pemeriksaan Steroid/Triterpenoid}

Sebanyak $1 \mathrm{~g}$ serbuk simplisia dimaserasi dengan eter selama 2 jam, kemudian disaring, filtrat sebanyak $5 \mathrm{ml}$ diuapkan dalam cawan penguap, kedalam residu ditambahkan 2 tetes asam asetat anhidrat kemudian ditambah beberapa tetes asam sulfat pekat. Bila terbentuk warna ungu - biru/hijau kemungkinan triterpenoid /steroid. 


\section{Pemeriksaan Saponin}

Sebanyak 1 gram serbuk simplisia ditambahkan $100 \mathrm{ml}$ air panas, dididihkan selama 15 menit kemudian di saring. Sebanyak $100 \mathrm{ml}$ filtrat dalam tabung reaksi dikocok vertikal selama 10 detik, dan didiamkan selama 10 menit. Hasil positif ditunjukkan dengan terbentuknya busa yang stabil, meskipun sudah ditambahkan beberapa tetes $\mathrm{HCl} 2$ N.

\section{Pemeriksaan Flavonoid}

Sebanyak $1 \mathrm{~g}$ serbuk simplisia ditambah $100 \mathrm{ml}$ air panas, didihkan selama 15 menit kemudian disaring. Filtrat sebanyak $5 \mathrm{ml}$ ditambah serbuk $\mathrm{Mg}$ dan ditambah $2 \mathrm{ml}$ larutan alkohol$\mathrm{HCl}$, dikocok kuat-kuat kemudian dibiarkan memisah. Pengamatan positif bila timbul warna merah/kuning/jingga pada lapisan atas.

\section{Pemeriksaan Tanin}

Sebanyak $1 \mathrm{~g}$ serbuk simplisia ditambahkan air panas $100 \mathrm{ml}$ air, dididihkan selama 15 menit kemudian disaring. Siapkan 3 tabung reaksi masingmasing berisi $5 \mathrm{ml}$ larutan filtrat. Tabung 1 direaksikan dengan larutan besi (III) klorida $1 \%$ (positif senyawa polifenol bila terbentuk warna biru tinta atau hitam kehijauan), tabung kedua ditambahkan gelatin (positif tanin bila terbentuk endapan putih), pada tabung ketiga ditambah pereaksi steasny (formaldehid $30 \%: \mathrm{HCl}$ 2:1) kemudian dipanaskan dalam penangas air 90 derajat Celcius (terbentuknya endapan merah muda menunjukkan simplisia positif mengandung tanin katekat), selanjutnya endapan pada tabung ketiga disaring dan filtrat ditambah dengan larutan besi (III) klorida $1 \%$ (terbentuknya warana biru tinta atau hitam kehijauan menunjukkan simplisia positif menunjukkan adanya tanin galat).

\section{Pemeriksaan Kuinon}

Sebanyak 1 gr serbuk ditambah $100 \mathrm{ml}$ air panas didihkan selama 15 menit kemudian disaring. Bila dalam sampel tidak terdapat tanin, maka ke dalam $5 \mathrm{ml}$ filtrat ditambah beberapa tetes $\mathrm{NaOH} 1 \mathrm{~N}$. Hasil positif bila terbentuk warna merah.

Jika ada tanin maka sejumlah $2 \mathrm{~g}$ serbuk sampel dimaserasi dalam HCL 19\% selama beberapa jam, lalu larutan disaring dan dibagi 2 , pada tabung 1 sebanyak $5 \mathrm{ml}$ diekstraksi dengan benzen dan tabung 2 sebanyak $5 \mathrm{ml}$ diekstaksi dengan campuran eter - klorform (2:1), kedua fase organik masing-masing dikeringkan dengan $\mathrm{Na}_{2} \mathrm{SO}_{4}$ anhidrat dan diuapkan sampai sepersepuluh $(0,5 \mathrm{ml})$. Kedua ekstrak masing-masing dikocok dengan larutan $\mathrm{NaOH} 30 \%$. Terjadinya warna jingga/merah violet menunjukkan adanya kuinon.

\section{HASIL DAN PEMBAHASAN}

Senyawa alkaloid positif pada simplisia daun beringin, daun kaumanis daun kopi, daun damar, daun pinus da daun sawo. Senyawa turunan fenolik (fenol, flavonoid dan tanin) dan saponin relatif ada pada semua tanaman, senyawa steroid/triterpenoid ada dalam semua simplisia serta kuinon hanya positif pada daun alpukat, daun kayu manis, daun sirsak, daun sawo, daun kayu putih. 
Tabel 1. Hasil penfisan fitokimia tanaman hasil inventarisasi Arboretum Garut

\begin{tabular}{|c|c|c|c|c|c|c|c|c|c|}
\hline \multirow[b]{2}{*}{ No. } & \multirow[b]{2}{*}{ Nama simplisia } & \multirow[b]{2}{*}{ Species } & \multicolumn{7}{|c|}{ Golongan Metabolit Sekunder } \\
\hline & & & Alkaloid & Fenol & Flavonoid & Tanin & Saponin & $\begin{array}{l}\text { Steroid/ } \\
\text { Triterpenoid }\end{array}$ & Kuinon \\
\hline 1 & Daun Alpukat & Persea americana & - & + & + & - & + & + & + \\
\hline 3 & Daun Kayu Manis & Cinnamomum verum & + & + & + & - & - & + & + \\
\hline 4 & Daun Kemiri & Aleurites moluccana & - & + & + & - & - & + & - \\
\hline 5 & Daun Kersen & Muntingia calabura & - & + & + & + & + & + & - \\
\hline 8 & Daun Mangga & Mangifera indica & - & + & + & + & + & + & - \\
\hline 9 & Daun Sirsak & Annona muricata & - & + & + & + & - & + & + \\
\hline 10 & Daun Jati & Tectona grandis & - & + & + & + & + & + & - \\
\hline 11 & Daun Kelengkeng & Dimocarpus longan & - & + & + & + & + & + & - \\
\hline 12 & Daun Damar & Agathis dammara & + & + & + & - & - & + & - \\
\hline 17 & Daun Sawo & Manilkara zapota & + & + & + & + & - & + & + \\
\hline 18 & Daun Puspa & Schima wallichi & - & + & + & + & + & + & - \\
\hline 19 & Daun Kayu putih & Melaleunca leucadendra & - & + & + & + & + & + & + \\
\hline 20 & Daun Jambu Bol & Syzigium malaccense & - & + & + & + & + & + & - \\
\hline 21 & Daun Jamblang & Syzigium cumini & - & + & + & + & + & + & - \\
\hline 22 & Daun Salam & Syzigium polyantum & - & + & + & + & + & + & - \\
\hline
\end{tabular}

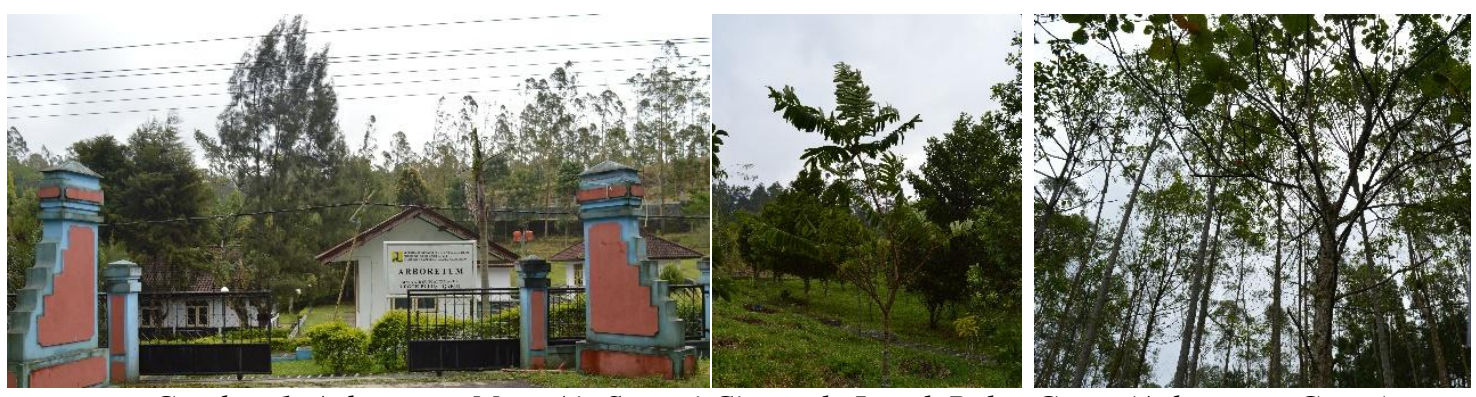

Gambar 1. Arboretum Mata Air Sungai Cimanuk, Legok Pulus Garut (Arboretum Garut)

\section{KESIMPULAN}

Dari hasil penelitian ini dapat disimpulkan bahwa dari dua puluh dua jenis tanaman yang terdapat di Arboretum Garut memiliki kandungan senyawa fitokimia beragam dan dapat dijadikan koleksi serta basis riset tanaman obat khususnya Fakultas MIPA Universitas Garut.

\section{UCAPAN TERIMAKASIH}

Kami mengucapkan terimasih kepada DRPM Kemristek Dikti Atas Bantuan Penelitian Dosen Pemula, Dekan Fakultas MIPA Universitas Garut, LPPM Universitas Garut dan Kepala Balai Besar Wilayah Sungai Cimanuk. Kementrian PUPR.

\section{DAFTAR PUSTAKA}

[1]. Popovic Z., Matic R.,Bojovic S., Stefanovic M.,Kovic V.,2016, Etnobotany and Herbal Medicine in Modern Complementary and Alternative Medicine : an Overview of Publication in the Field of I\&C Medicine 2001-2013, Journal of Etnhopharmacology (Accepted Manuscript).

[2]. Sukara E., 2014, Tropical Forest Biodiversity to Provide Food, Health and Energy Solution of to the Rapid Growth of Modern Security, Proceedia Enviromental Science 20 hal. 803-808.

[3]. Dimyati E., Nanda A., Pratiwi Y., 2015, Garut Swiss Van Java, Penerbit Buku Kompas Hal xv. 
[4]. Yulianti S., 2015, Inventarisasi Tanaman Obat di Arboretum (Bukit 1) Kecamatan Samarang Kabupaten Garut, Skripsi Program Studi Farmasi, Fakultas Matematika dan Ilmu Pengetahuan Alam, Universitas Garut.
[5]. Depkes R.I. 1979. Materia Medika Indonesia. Jilid III. Jakarta : Ditjen POM

[6]. Jacson P.W dan Sutherland L.A., 2013 Role Of Botanic Garden, Encyclopedia of Biodiversity Vol. 6 hal 504

[7.]. Anonim, 1985, Cara Pembuatan Simplisia, Departemen Kesehatan RI.

How to cited this article :

Handayani R, Rustamsyah A, Perdana F, Ihsan S, Suwandi DW. 2017. Studi Pendahuluan Fitokimia

Tanaman Koleksi Arboretum Legok Pulus Garut, J. Trop. Pharm. Chem. (4)2. 101-104. 